\title{
Applicability of the Liability Convention for Private Spaceflight
}

\author{
Guoyu Wang $\mathbb{D}$ and Chao Li \\ Academy of Air, Space Policy and Law, Beijing Institute of Technology, Beijing 100081, China \\ Correspondence should be addressed to Chao Li; 1716900597@qq.com
}

Received 28 January 2021; Accepted 30 March 2021; Published 4 May 2021

Copyright ( 2021 Guoyu Wang and Chao Li. Exclusive Licensee Beijing Institute of Technology Press. Distributed under a Creative Commons Attribution License (CC BY 4.0).

While the era of private spaceflight is coming, it is getting urgent to have common understanding about the existing space legal systems, i.e., the Applicability of the Liability Convention (ALC) in handling with damage which might occur during space tourism. The applicability of the relevant articles about absolute liability, fault liability, and claimant State is systematically analyzed. The paper in turn analyzes the ALC in the situation of the participants suffering damage and in that of the participants causing damage, as a dichotomy methodology. The LC applies to a private spaceflight participant when they suffer damage on board during the spaceflight. As to the eligible claimant State, in the absence of the nationality State, the registry State, or the owner State of the space object may present the claim instead. If damage to the foreign participants on board happened on the surface of the earth, the nationality State of the participant could present claim to the launching State to protect its national's interests under general international law rather than under LC. If the damage happens to the foreign participants on board happened elsewhere than on the surface of the earth, Article III of the LC could only apply in limited situations. Only when a spacecraft for private spaceflight of/or registered by one State is carried by the launching vehicle of another State, Article III applies. The best solution in such colaunching situation is to settle down the rights, obligations, and liabilities specifically in a binding international agreement between the launching States. The absolute liability should apply when a space object causes damage to a spaceship carried on by an aircraft before it separates from each other. After the separation, fault-based liability applies to the damage happening to spaceship. The registry State of a space object should be responsible for participants thereof who caused damage to the space object of a third-party State. The LC then applies when the damage is caused by the fault of the participant. If the spaceship is not registered, the launching State shall be responsible for the participants involved its "national activities," no matter if the participant is its nationals or foreigners and the damage caused by them based on their fault, while the nationality State is not supposed to be responsible for its nationals in such case. At last, issuing a space visa to the participant of private spaceflight could be taken as a compliment measure for the State to implement its authorization obligation as to its national space activities, which could bring more legal certainties when defining the fault attribution.

\section{Introduction}

1.1. Space Tourism and Private Spaceflight. In international law, there is no definition for private spaceflight. The commentators have suggested different definitions for private space flights or space tourism. One of the most widely accepted definitions of the term "space tourism" is "any commercial activity that offers customers direct or indirect experience with space travel" [1].

Such activities have many different designs, ranging from long-term stays in orbital facilities to short-term orbital or suborbital flights, and even parabolic flights in an aircraft exposing passengers to short periods of weightlessness [2].
"Private human spaceflight should be defined as "flights of humans intended to enter outer space (a) at their own expense or that of another private person or private entity, (b) conducted by private entities, or (c) both" [3].

The private spaceflight in this paper shares the same range with "space tourism" defined above. From the perspective of connotation, there are no substantive differences between them. In addition, it is not limited to spaceflight "conducted by private entities" only. It could also be conducted by a government or a stated-owned corporation. Moreover, from a forward-looking perspective, the purpose of a private spaceflight in the future might be just as one kind of transportation rather than enjoying the tour per se. 
Therefore, as some commentator expresses it: "private spaceflight is the more precise and more helpful term for the purpose of legal analysis" [4]. It should be mentioned that "private spaceflight" in this paper has no intention to distinguish orbital flight and suborbital flight, which is as "a flight up to a very high altitude which does not involve sending the vehicle into orbit" [5]. Subsequently, the definition and delimitation of air and outer space are not within the scope of this discussion. There is no internationally accepted or uniform understanding of where outer space begins. Its delimitation from airspace is contested [6].

The paper is aimed at seeking for as many solutions and certainties as we can find from the existing international space legal regime, especially in space treaties.

\subsection{Liability in International Space Law and National Law as} to Private Spaceflight. Liability is a critical one among all legal issues about private spaceflight. The liability regime, in particular, has a significant impact on the viability of the space tourism industry and its ability to manage cost and risk as it grows into maturity [7]. Matters of liability are of major interest to operators of space tourism activities who need to assess their potential financial risk [8].

There are many researches on the legal regimes at national law level [9]. As to liability, several industry observers have concluded that limits on liability are a requirement if the space tourism industry is to flourish [10]. By comparison, there is less research focusing on the liability issue in international space law [11].

This paper focuses on the analysis of the liability regime in the 1972 Liability Convention [12], in particular to examine its applicability to private spaceflight. Specifically, the applicability of the articles about absolute liability, fault liability, and claimant State is systematically and deeply analyzed. The paper in turn analyzes the applicability of the Liability Convention in the situation of the participants suffering damage and in that of the participants causing damage, as a dichotomy methodology.

\section{The Applicability of the Liability Convention to the Private Spaceflight when the Participant Suffers Damage}

It is unclear whether the Liability Convention can apply to passengers of a space object [13]. Further, the prerequisite question to be answered is whether the Liability Convention applies to a private spaceflight participant, respectively, to nationals and foreigners.

It is interesting to refer back to the U.S. legislation, which also introduces, as we have seen, the notion of "space flight participant." The term is defined as "an individual, who is not crew, carried within a launch vehicle or reentry vehicle" [14].

2.1. The Applicability to a Foreign Participant as Victims. Article VII of the Liability Convention makes it clear that the Liability Convention does not apply to damage caused by a space object of a launching state to nationals of that same state [15]. Besides, whether it applies to "foreigners" should be discussed.

Pursued to Article VII, the Liability Convention is not applicable to "foreign nationals during such time as they are participating in the operation of that space object from the time of its launching or at any stage thereafter until its descent, or during such time as they are in the immediate vicinity of a planned launching or recovery area as the result of an invitation by that launching State" [16].

Therefore, it does not apply to foreign nationals when they are invited to observe the launching or landing. But literally, it does not exclude the applicability to foreign space tourists. Moreover, Article VIII of the Liability Convention indicates that the foreign space tourists' State of nationality is vested with the right of claim for compensation representing its nationals under this Convention. It stipulates that a "State which suffers damage, or whose natural or juridical persons suffer damage, may present to a launching State a claim for compensation for such damage" [17].

Even so, the occasions in which a nationality State could represent its victims for a compensation to a launching State are limited by the Liability Convention. The Liability Convention should be examined integrally regarding its applicability to foreign space tourists.

2.2. The Applicability to a Claimant State, Absolute, and Fault Liability. The key question to be discuss in this part is which State is entitled to claim for the compensation representing the victims. Art. VIII of the Liability Convention stipulates that

(1) a State which suffers damage, or whose natural or juridical persons suffer damage, may present to a launching State a claim for compensation for such damage

(2) if the State of nationality has not presented a claim, another State may, in respect of damage sustained in its territory by any natural or juridical person, present a claim to a launching State

(3) if neither the State of nationality nor the State in whose territory the damage was sustained has presented a claim or notified its intention of presenting a claim, another State may, in respect of damage sustained by its permanent residents, present a claim to a launching State [18]

Article VIII of the Liability Convention offers three approaches, whereby victim(s) of space damage may rely on particular legal or factual links to a State [19]. It sets up the eligibility of claimant State, which are, respectively, national State, terrestrial State, and residential State [20].

These occasions could be envisaged basing on Articles I, II, and III of the Liability Convention. Article I (a) sets up the scope of "damage": "The term 'damage' means loss of life, personal injury or other impairment of health; or loss of or damage to property of States or of persons, natural or 
juridical, or property of international intergovernmental organizations." Articles II and III, respectively, stipulate absolute liability and fault-based liability.

"A launching State shall be absolutely liable to pay compensation for damage caused by its space object on the surface of the earth or to aircraft in flight" [21]. "In the event of damage being caused elsewhere than on the surface of the earth to a space object of one launching State or to persons or property on board such a space object by a space object of another launching State, the latter shall be liable only if the damage is due to its fault or the fault of persons for whom it is responsible" [22].

In respect of the above articles, these occasions regarding the applicability of them to a foreign space tourist could be examined in hypothetical cases.

2.2.1. Damage Caused by a Third-Party State. State A refers to a launching State which provides a private spaceflight service, State $\mathrm{B}$ refers to the State of nationality of the private spaceflight participant, and State C refers to another launching State whose space object causes damage to the participant in any stage of the flight. Taking the participant (foreign tourist) as the main clue, it could be analyzed in the following categories ("Apply" refers to the Liability Convention applying in the listed situation; "Not Apply" refers to the contrary):

(1) "Apply": Damage Happens Elsewhere Than on the Surface of the Earth Caused by the Space Object of the Third Party. (A) State of Nationality. Assume that the space object of $C$ causes damage to the spaceship of A and the foreign participates on board elsewhere than on the surface of the earth. Based on Articles III and VIII, the Liability Convention applies and State $\mathrm{B}$ may claim against $\mathrm{C}$ for compensation as the national State of the participant.

In this case, another question is whether State $\mathrm{A}$, the launching service provider, could represent the victim to against to the launching State $\mathrm{C}$ ? The answer might be different under another paragraph of Article VIII of the Liability Convention.

Paragraph 2 of Article VIII also addresses the right of the State sustaining damage to present a claim for the victims in certain circumstances. "If the State of nationality has not presented a claim, another State may, in respect of damage sustained in its territory by any natural or juridical person, present a claim to a launching State" [23]. In its second paragraph, Article VIII thereafter stipulates that a state other than that of the claimant's nationality may present a claim to a launching state. In this case, damage must have taken place in the latter's territory and the damage must have occurred to any natural or juridical person [24].

(B) Registry State in the Second Paragraph of Article VIII. Suppose the State of nationality B does not present the claim for its nationals, then the logical precondition for State A to present the claim is that the spacecraft launched by it should be proved to be in its territory.
It is hard to claim that a space object is in the territory of its launching State, even if it is already on its registry. Some commentators deem a space object as quasiterritory. "In between territorial jurisdiction and personal jurisdiction stands quasi-territorial jurisdiction. This is the sum total of the powers of state in respect of ships, aircraft and spacecraft (to the extent to which they are also granted legal personality) having its nationality or registration. Quasi-territorial jurisdiction differs from personal jurisdiction in that it extends not only to the craft in question but also to all persons and things on board, including the activities of such persons, whether on board the craft or elsewhere" [25]. Even if the spacecraft is the quasiterritory of launching State A, it still could not exactly match up with "territory" requirements. Thus, State A could not present a claim to $C$ pursuant to the second paragraph of Article VIII.

(C) Registry State in the First Paragraph of Article VIII. However, State A might be granted the eligibility of claimant State pursuant to the first paragraph of Article VIII. The first paragraph of Article VIII addresses the general principle according to which a State may present a claim to a launching State for compensation on either of two occurrences [26]. "A State which suffers damage, or whose natural or juridical persons suffer damage, may present to a launching State a claim for compensation for such damage" [27].

The crux is how to interpret the genitive "whose." "It makes no direct reference to the status of a victim's 'nationality', the use of the genitive 'whose' confirms that the Article VIII refers to those with whom the State has establishs legal relations, particularly through nationality under domestic law. Normally, the State presents the claim is likely to be the State of nationality" [28]. It also indicates there might be other legal relations that could fit in the implication of "whose," for instance, the registry of the space object.

Registry stands for the jurisdiction and control over the space object registered and personnel thereof, according to Article VIII of the Outer Space Treaty. "A State Party to the Treaty on whose registry an object launched into outer space is carried shall retain jurisdiction and control over such object, and over any personnel thereof, while in outer space or on a celestial body" [29]. The "jurisdiction and control" undoubtedly established a genuine link between the registry State and the participant, which should also satisfy the "whose" formulation. Therefore, State A may present claim to State $\mathrm{C}$ as a registry State as well.

(D) Owner State of the Space Object. If the spaceship is not registered due to all kinds of reasons, then the qualification of a claimant State of A would be in question. If State A is the owner State of the spacecraft, then there are still legal reasons supporting to grant it claimant State title, according to Article VIII of the Outer Space Treaty. "...Ownership of objects launched into outer space, including objects landed or constructed on a celestial body, and of their component parts, is not affected by their presence in outer space or on a celestial body or by their return to the Earth..." [30]. 
Likewise, ownership builds up legal relations between State $A$ and the participant on board. However, the support from "ownership" is not as strong as "jurisdiction and control," since international space law only grants the right of jurisdiction and control to a registry State. In this case, whether an owner State of the spacecraft could present a claim under paragraph 1 of Article VIII of the Liability Convention is uncertain.

Considering the "victim-oriented principle" enshrined in the Liability Convention, the owner State should also be granted the title of claimant State under paragraph 1 of Article VIII, in that it could offer more opportunities to the victims to fulfill their claims.

Therefore, States A and B could both become the victim's diplomatic representative in its claim for compensation under the Liability Convention and the Convention may be applied in this hypothetical case.

It should be noted that most likely in practice, the owner of the spacecraft will be a private sector company rather than a State to provide private spaceflight service. If so, the links between the launching State and the participant become less tight and significant. The launching or relevant license could only prove the tight connections between a State and a private sector company, rather than to both parties of the private spaceflight contract. In this case, it is not proper to grant a license launching State the eligibility of claimant State based on the legal scope of "whose" in paragraph 1 of Article VIII of the Liability Convention, let alone any other links less tight as a license.

Nevertheless, the idea of "space visa" [31] should be examined as to define the extent of links between the spaceflight service provider State, which grants the space visa, and the participant who is granted the visa. This kind of space visa will establish certain legal authorization relations directly between the State and the participant. Therefore, the State who grants the space visa to the spaceflight participant may be qualified to present a claim for the injured or dead participant under paragraph 1 of Article VIII as well.

(2) "Apply": Damage on the Surface of the Earth Caused by the Space Object of the Third Party. Assume that the space object of $C$ State conducts a reentry and causes damage to the spaceship of $\mathrm{A}$ and the foreign participate on board on the surface of the earth. Based on Articles II and VIII, the Liability Convention applies.

As discussed above, State B may present a claim to State C for compensation as a State of nationality and State A may present the claim as a territorial State which sustains damage when the national State has not presented the claim for its nationals. Thus, the Liability Convention applies in this case as well.

However, it should be added that when the launching facility locates on high seas, it is could hardly be recognized as the territory of the launching State. It means paragraph 1 of the Article VIII cannot apply in this case.

2.2.2. Damage Happens during the Implementation of a Private Spaceflight Contract, without Interference from a Third Party. Based on the different locations set up in Articles II and III of the Liability Convention, it could be discussed in two circumstances.
(1) "Not Apply": Assume Damage to the Foreign Participants on Board Happened on the Surface of the Earth and It Might Be Caused, For Instance, by an Explosion of the Launching Vehicle or Spacecraft. Under those circumstances, whether the participant's national State could claim to the launching State under paragraph 1 of Article VIII of the Liability Convention is uncertain. Subsequently, the applicability of the Convention is uncertain too.

(A) The Applicability of Article II. "A launching State shall be absolutely liable to pay compensation for damage caused by its space object on the surface of the earth or to aircraft in flight" [32]. The crux is that whether the real intention of Article II of the Convention also covers damage caused by a space object before it is launched into outer space. To protect the people and property on the space object which still stands on the launching site was not the concern of the Legal Subcommittee during the negotiation of drafting the Liability Convention. "Three concerns were prevalent in the Legal Subcommittee sessions: firstly, the 'dimensional' aspect of the Convention as to what was encompassed by the concept of damage on Earth; secondly, the nature of damage to be covered by the Convention, and finally, which legal and natural persons or interests were to be protected by the Convention's provisions" [33].

Besides, most likely, the original intention of Article II is to protect the people and property of nonspacefaring countries from damage caused by the space objects of the U.S. and the U.S.S.R. "Absolute liability would impose greater duties on spacefaring States -there were only two major space powers at that time-and provide protection for the nonspacefaring countries which to a large extent included the developing States" [34].

If the provision is interpreted "in the light of its object and purpose" [35], the national State of the participant could not present a claim to the launching State, in that Article II does not apply. And as stated above, Article VIII should be examined together with the previous articles when defining its applicability.

However, under general international law, the State of nationality could present a claim to the launching State to protect its national's interests. "Under general international law, a state may present claims against another in respect of damage suffered by itself or its nationals, but not damage suffered by nationals of another state or by stateless persons" [36].

(B) To Define "Launching State". Besides, whether the "launching State" could be defined as a launching State is not certain either. In the above hypothetical case, it could be deemed as a failed launching. "From the early phrase of the negotiation, there was agreement that neither a successful launch nor use of the space object launched in outer space should be pre-requisites to liability" [37]. Article I (b) states that "the term 'launching' includes attempted launching." Therefore, it should be deemed as a launching State even though it conducted a failed launching during the static firing or any other attempts. 
(2) "Apply/Not Apply": Assume Damage to the Foreign Participants on Board Happened Elsewhere Than on the Surface of the Earth and It Might Be Caused by an Explosion of the Launching Vehicle or Spacecraft. Obviously, Article III of the Liability Convention only covers damage happening between two space objects [38]. Therefore, it does not apply in this case, neither does apply Article VIII. The State of nationality could not claim compensation for the participant under the Liability Convention.

Meantime, it also offers the possibilities for the Liability Convention application in certain circumstances. Assuming a spacecraft for private spaceflight of/or registered by one State is propelled by the launching vehicle of another State, the former State might have rights to claim against the latter State when its national space tourists on board suffer damage due to the flaws of the launching vehicle or any fault which could be attributed to the latter State.

However, the applicability of the Liability Convention in the above case is still debatable, since in most occasions the former State would be considered a launching State for the spacecraft or spaceship as well as the latter State. Some commentator pointed out that "Article III of the Liability Convention clearly refers to cases where third parties are involved, so that fault-based liability cannot be applied with respect to passengers" [39]. But the Liability Convention does not articulate that fault-based liability only applies when damage happens between separated space activities. Literally, fault-based liability applies as long as damage happens between different space objects and different launching States [40].

The best solution in this colaunching situation is to settle down the rights, obligations, and liabilities specifically in a binding international agreement between the launching States. The agreement will prevail over the Liability Convention to apply among the relevant States according to Art. XXIII of the Liability Convention, which stipulates that "(1) The provisions of this Convention shall not affect other international agreements in force in so far as relations between the States Parties to such agreements are concerned. (2) No provision of this Convention shall prevent States from concluding international agreements reaffirming, supplementing or extending its provisions" [41].

(A) The Applicability to a Hybrid Spaceflight. The applicability of the claimant State will be even complicated in a hybrid launching with an aircraft and a spaceship, since an aircraft could not be defined as a launching vehicle. For instance, Virgin Galactic's human spaceflight system consists of two vehicle types: WhiteKnightTwo and SpaceShipTwo [42].

2.2.3. General Principle of the Application of Air and Space Law. As commentators stated: "If space tourism activities are modelled on SpaceShipOne, the law governing liability will likely be determined based on whether the space vehicle is still attached to the aircraft or whether the two objects have separated. When the aircraft is attached to the suborbital vehicle, the relevant air law provisions may be applicable. ... Once separated, space law, such as the Liability Conven- tion of 1972, may apply to the suborbital vehicle using rocket propulsion for thrust. The Liability Convention would also apply to both space objects if the space capsule is launched by a rocket" [43].

\subsubsection{The Applicability of the Liability Convention, Inter Alia, Articles II, III, and VIII}

(1) Damage Happens on the Surface of the Earth. On this occasion, it does not differentiate from the normal private spaceflight. When damages are caused by a space object of a second or other party, both Articles II and VIII apply. Otherwise, they do not apply if the damage is not caused by a third party. It should be deemed as an "attempt" launching no matter the failure originated from the aircraft or the spaceship.

(2) Damage Happens in the Air. It brings more complications from the air. First, it might be not easy to define the applicability of the Convention when damage is caused by another space object during its reentry. Then, the launching State shall be absolutely liable for the damaged caused by its space object to the aircraft in flight according to Article II of the Liability Convention [44].

But what if the first point of impact by the crash is the spaceship rather than the aircraft? Does Article III apply since it is damaged between two space objects and it happens elsewhere than on the surface of the earth? Literally, the answer is yes. "In practice, it means that an accident between two space objects which have not yet reached outer space will fall under Art. III, insofar as the conditions of Art. II are not met" [45].

However, it should not be the case. The purpose of the distinctions between application fields in the relevant articles should be examined. The dichotomy of damage fields of the Convention is to avoid a delimitation between airspace and outer space. It should not be aiming at differentiating aircraft and space object when either of them is crashed into by another space debris in the same altitude, inter ilia, in airspace.

Besides, the rationale of the dichotomy of forms of liabilities should be examined. As addressed by some commentators that "the rationale for unlimited liability under the Liability Convention, which is an exception to the general rule under international law, is to enable full compensation to be made available in a situation of ultra-hazardous risk" [46]. Moreover, the rationale for absolute liability always means to protect something more valuable or deserving more attentions to protect. In this respect, an aircraft in flight with passengers on board and a spacecraft in flight in airspace with participants should not be differentiated as to the form of liability, even if the amount of participants might be much smaller than the passengers on an aircraft in short term.

Therefore, the absolute liability should apply when a space object causes damage to a spaceship carried on by an aircraft before they separate from each other. After the separation, fault-based liability applies to the damage happening to spaceship. 
If the damage is not caused by a third party, air law applies before the separation. After separation, as the aforementioned, Article III only applies between two space objects; therefore, the Liability Convention does not apply under these circumstances either.

\subsection{The Applicability of the Liability Convention to Private Spaceflight when the Participant Causes Damage}

\subsubsection{Liability Applicable Based on Damage to Another Space} Object Caused by Private Spaceflight Participants under Article III of the Liability Convention

(1) Fault Liability. Article III of the Liability Convention stipulates that: "In the event of damage being caused elsewhere than on the surface of the earth to a space object of one launching State or to persons or property on board such a space object by a space object of another launching State, the latter shall be liable only if the damage is due to its fault or the fault of persons for whom it is responsible" [47].

Fault-based liability of the space objects' launching state applies to damage caused by a space object other than on the surface of the Earth, to a space object of another launching state, or to persons or property on board such space object [48]. In this paper, the third party's liability based on damage caused by and to another space object is discussed separately. The former has been analyzed in the above parts. This part discusses the applicability of the Liability Convention when a space object of another launching State is damaged due to the fault of the participant during a private spaceflight.

Then who shall be liable for the damage according to the Liability Convention? Launching State of the spaceship/space capsule? Registry State? Or the nationality State of the participant or all/some of them? Apparently, the attribution of the fault of persons to a launching State is the crux for the applicability of Article III in a private spaceflight.

(2) Fault Attribution: "Persons for Whom the Launching State Is Responsible". The "persons" whose fault caused the damage might be the persons on ground who are responsible for the Telemetry, Tracking, and Command; the captain on board of the spaceship/space capsule; or any personnel thereof, including the private spaceflight participant.

However, there must still be some legal links between the launching State and the participant who causes damage. The legal recognized in Article III is to be a "persons for whom the launching State is responsible." Therefore, if it could be proved that the launching State shall be responsible for the participant, Article III of the Liability Convention applies. That link should be discussed in two situations: a spaceship is registered and is not registered.

(A) Spaceship Registered (Jurisdiction and Responsibility). Registration of a space object builds up legal links between a launching State and the personnel thereof. Article VIII of the Outer Space Treaty stipulates that: “(A) State Party to the Treaty on whose registry an object launched into outer space is carried shall retain jurisdiction and control over such object, and over any personnel thereof, while in outer space or on a celestial body..." Article VIII of the Outer Space Treaty was not intended to exempt passengers from the jurisdiction and control of the state of registry [49].

Therefore, the question is whether "jurisdiction and control" is a sufficient reason to prove "being responsible for." Jurisdiction means "A government's general power to exercise authority over all persons and things within its territory" [50]. As commentators address that "( $\mathrm{t}$ )he jurisdiction referred to in Article VIII is quasi-territorial rather than personal in character, for it applies to not only the spacecraft but also any personnel on board, irrespective of their nationality. The quasi-territorial jurisdiction of the state of registry overrides, therefore, the personal jurisdiction of the national state, at least insofar as the power of enforcement or implementation ('jurisdiction')" [51].

As far as the author is concerned, "jurisdiction and control" should be taken as not only a legal resource for "being responsible for" but also the strongest one. Therefore, the Liability Convention applies when the damage to another space object is due to the fault of the participant on board, and the fault is attributed to the launching State of the spaceship which is registered by it, since it is responsible for the participant under the Outer Space Treaty.

What if the participant is not on board but is outside the spaceship, for instance, to conduct space walking, is the registry State still responsible for him/her? The answer is yes. The jurisdiction of the state of registry applies to these persons, not only when they are on board, but also when they are outside their vehicle [52]. To the extent that they are members of the crew [53] of space vehicles, the treaty envisages therefore that all persons in outer space and on celestial bodies will be subject to the quasiterritorial jurisdiction of the state of registry of their respective spacecraft, irrespective of their own nationality [54].

In fact, to be totally comprehensive, national activities should include all activities by whomsoever carried on within the jurisdiction of a state, including its territorial jurisdiction, quasiterritorial jurisdiction, and personal jurisdiction. Thus, in addition to activities carried on by a state's nationals, wherever they may be, and those by any person within a state's territory, one should include within the notion of "national activities" also those by, or on board, ships and aircraft of a state's nationality, wherever these ships or aircraft may be and irrespective of the nationality of the persons involved [55].

Thus, the responsibility of the registry State for the private spaceflight participants extends into outer space. It brings another question, for how long and to what extent this responsibility exists? At least, the spaceflight contract should be taken into considerations as to define the period or scope of such responsibilities. The optimal way to clarify relevant issues is to make them clear under international space law. Otherwise, the boundary of responsibilities among the launching State, the private sector who provides spaceflight services, and the participants could only be defined in the 
contract or national laws, which has no legal effect for the third party beyond such contractual or national legal relations.

The above legal links built up between a launching State and a participant are based on registration. Then what if the spaceship/space vehicle/space capsule is not registered? Does the Liability Convention still apply?

(B) Spaceship Not Registered ("National Space Activity" and Responsibility). As stated above, jurisdiction is a legal resource of responsibility. But it is not the only legal resource of responsibility. The legal links still exist between a launching State and a private spaceflight participant without registration under international space law, which could establish a "responsible" legal relation between them.

Article VI sentence 1 of the Outer Space Treaty states that State Parties shall bear international responsibility for national activities in outer space. "States Parties to the Treaty shall bear international responsibility for national activities in outer space, including the moon and other celestial bodies, whether such activities are carried on by governmental agencies or by non-governmental entities, and for assuring that national activities are carried out in conformity with the provisions set forth in the present Treaty" [56].

It should be noted that, literally, it only addresses the "responsible" relations between a State and space activities carried on by governmental agencies and nongovernmental entities but does not directly mention space activities conducted by persons/individuals. Some commentators hold that "non-governmental entities" include individuals. "nongovernmental entities" [57] are not directly bound by the Treaty ratified by the State, i.e., entities that are not exercising supreme State authority. These are natural and legal persons of private law, as well as universities and research organizations (even where they are run as public statutory corporations) [58].

However, Black's Law Dictionary defines "entity" as "(A)n organization (such as a business or a governmental unit) that has a legal identity apart from its members." Apparently, its connotation does not include individuals or natural persons, whereas, in Chinese, “实体(entity)” refers to something that exists separately from things, including humans and objects [59].

To say the least, even if the scope of space actors, who carry on space activities in Article VI of the Outer Space Treaty, does not include individuals, the participant's activity during a private spaceflight should be deemed as part of the space activities carried on by the service provider, which might be a non-governmental entity. Then, it should be also taken as "national activities" for which a State is responsible.

Even so, it still needs further clarification to prove the applicability of Article III of the Liability Convention as to the fault attribution, in that "be responsible for national activities" is not equal to "be responsible for persons who carry on the activities." Again, the "victims-orientated" principle reflected in the Liability Convention should be kept in mind under this circumstance. Obviously, it is not conducive to define a responsible subject/body State if one interprets it in a narrow meaning. It will generate a "legal vacuum" if claiming "responsibility for activities" could not include "responsible for whosoever carries on such activities."

Therefore, Art. III of the Liability Convention applies when damage happens to the space object of another launching State, caused by the fault of the participant, in that the launching State shall be responsible for the participants in its "national activities," no matter whether the participant is its nationals or foreigners.

The above "responsibility links" between a participant and a launching State need to be discussed specifically to facilitate affirming the applicability of the Liability Convention in this case.

\subsubsection{Space Visa: To Better Confirm the Responsibility Relations between a State and a Participant}

(1) The Launching State's Responsibilities for Private Spaceflight Participants. According to Article VI of the Outer Space Treaty, "authorization and continuing supervision" should be taken as one of the forms of the "appropriate State" to bear its international responsibility. "...The activities of nongovernmental entities in outer space, including the Moon and other celestial bodies, shall require authorization and continuing supervision by the appropriate State Party to the Treaty" [60].

Authorization could always be taken as the "proof" for confirming the relations of responsibility between a State, in particular a launching State and a non-governmental entity or an individual. "The authorisation conditions can be implemented within a general legislation, often called national space legislation; but it can also be implemented by other means" [61].

In general practices, the typical tools for authorization of a launching State include granting a license for the private spaceflight, requesting insurance, etc.

Therefore, the State which issues licenses to a private spaceflight shall be responsible for the flight and the space actors, including the participants who carry on this flight, and in most occasions, this State should be defined as a launching State since it procures the launching [62].

The paradoxical question is whether "authorization" is the one of the requirements of a State's responsibilities or a precondition to establish the relationship of responsibility between the State and the space activities it is going to authorize. The question could be reiterated as "without authorization, without responsibilities" or "responsibility means authorization of obligations"? It seems that the latter should be correct, that means the "authorization," for instance, to issue a license, is the due obligation of a State which is responsible for a space activities or its participants.

However, this view might be improperly enlarged under general international law. "State responsibility has to be determined by general aspects of public international law, $i$. e. a State has jurisdiction over any activity that is carried on from its territory as well as over any activity that is carried on by its nationals (natural or juridical persons). However, many different views exist" [63]. 
The crucial question is whether a national State of a participant has the obligation to authorize or supervise its nationals in the spaceflight being under taken by another State or by the service provider beyond its jurisdiction. It is still an open question in international space law.

As far as the author is concerned, the answer should be no. If the answer be yes, it would bring an improper burden on the national State to authorize or supervise its national participant. For instance, it would be unnecessary for the participants to ask for permission from their national State before they participate a private spaceflight overseas.

On the other hand, in line with the principle of correspondence of right and obligation in jurisprudence, the above national State is not supposed to be responsible for its nationals during the private spaceflight, in that it is not supposed to have the right of permission for the participation of its nationals either.

(2) Space Visa: An Idea to Bring More Legal Certainties. "The space visa is apt for a variety of reasons. While it could be titled a license or permit, the analogy of the visa is particularly appropriate due to the emerging focus on space tourism and the existing parallels between space tourism and terrestrial tourism" [64]. The visa is used to control the flow of peoples over international boundaries and airports often serve as the border area in which passports and visas are presented. A spaceport will serve the same functions as an airport, and it, similarly, should also be treated as a boundary area for people passing into space; thus, the space visa will fit neatly into preexisting and internationally accepted regime" [65].

Inspired by this idea, the space visa should be considered a specific legal tie between a launching State and a participant, no matter whether nationals or foreigners. As analyzed above, there are no direct or clear legal links between them, which would lead to uncertainties when the fault attribution of the participant needs to be confirmed, especially when the spaceship is not registered.

A Space visa granted by the launching State to a private spaceflight participant acts as a similar function with a license issued by the same State, which could arrange specific rights and obligations among State and spaceflight participants, such as risks allocation, safety or healthy standards, and insurance requirements. The period and scope of "responsibility" could also be articulated in such a space visa. To issue a space visa to the participant of private spaceflight could be taken as a complimenting measure for the State to implement its authorization obligation as to its national space activities.

\section{Conclusion}

The era of private spaceflight is coming. "The tide of space tourism waits for no law-but the rule of law must prevail in the exploration and use of outer space" [66]. Comparing with the desired final solution as to definition and delimitation of air and space and any other analogous puzzle, it is more practical and urgent to have common understanding about the existing space legal systems, such as the applicability of the Liability Convention, which is the main target of this paper and is just a preliminary endeavor to analyze the whole international law systems.

The main conclusions of this paper are as follows.

3.1. Participants Suffer Damage Caused by a Third-Party State. The Liability Convention applies to a private spaceflight participant, respectively, to nationals and foreigners, when they suffer damage on board during the spaceflight.

As to the eligible claimant State, it is no doubt that the nationality State of the victims may present claims to the launching State whose space object causes the damage. In the absence of the nationality State, the registry State of the spaceship/space capsule/space vehicle may present the claim instead, given the registered space object could be deemed as its quasiterritory.

If the "registration" could be interpreted to fit in the implication of "whose" in the first paragraph of Article VIII of the Liability Convention, then the registry State becomes an alternative option to State of nationality to raise claims for compensation in the first place. That interpretation should be considered, in that a larger scope of eligible claimant States is conducive to protect the interests of the victims.

If the spaceship is not registered, whether an owner State of the spacecraft could present a claim under paragraph 1 of Article VIII of the Liability Convention is uncertain. Considering the "victim-oriented principle" enshrined in the Liability Convention, the ownership State should also be granted the title of claimant State.

\subsection{Participants Suffer Damage Caused by a Non-Third-Party} State. If damage to the foreign participants on board happens on the surface of the earth which might be caused, for instance, by explosion of the launching vehicle or spacecraft, the nationality State of the participant could not present a claim to the launching State, in that Article II of the Liability Convention does not apply. Instead, under general international law, the nationality State could present claim to the launching State to protect its national's interests.

If the damage happens to the foreign participants on board elsewhere than on the surface of the earth due to, for instance, explosion of the launching vehicle or spacecraft, Article III of the Liability Convention could apply in very limited situations, in that it only applies between two space objects. Even if a spacecraft for private spaceflight of/or registered by one State, which could be deemed as the "procured" launching State, is carried by the launching vehicle of another State, whether Art. III of the Liability Convention applies is still uncertain in that the two States would be deemed as colaunching State of both the spacecraft and the launching vehicle.

The best solution in such colaunching situation is to settle down the rights, obligations, and liabilities specifically in a binding international agreement between the launching States.

3.3. A Hybrid Spaceflight. If damage happens on the surface of the earth, which is caused by a space object of a thirdparty, both Articles II and VIII apply. Otherwise, they do not apply if the damage is not caused by a third party. 
If damage happens in the air, which is caused by another space object during its reentry, the launching State shall be absolutely liable for the damaged caused by its space object to the aircraft in flight. But if the first point of impact by the crash is the spaceship rather than the aircraft, Article III should not apply only because of the different crashing part, in that the allocation of absolute or fault-based liability should not be decided by contingency. The rationale for absolute liability always means to protect something more valuable or deserving more attentions to protect.

Therefore, the absolute liability should apply when a space object causes damage to a spaceship carried on by an aircraft before it separates from each other. After the separation, fault-based liability applies to the damage happening to spaceship.

3.4. Participants Cause Damage to the Space Object of a Third-Party State. The confirmation of "fault attribution," or in other words, to confirm the legal relation of "persons for whom the launching state is responsible," is the focus in this part.

If the spaceship is registered, the registry State should be responsible for participants thereof due to its jurisdiction. Then, Article III of the Liability Convention applies when the damage is caused by the fault of the participant.

If the spaceship is not registered, Art. III of the liability applies when damage happens to the space object of another launching State, caused by the fault of the participant, in that the launching State shall be responsible for the participants in its "national activities," no matter the participant is its nationals or foreigners.

A nationality State of a participant should not have the obligation to authorize or supervise its nationals in the spaceflight being taken by another State or by the service provider beyond its jurisdiction, in that it would bring improper burden of the nationality State. Correspondingly, the above nationality State is not supposed to be responsible for its nationals during the private spaceflight.

3.5. Space Visa. To issue a space visa to the participant of private spaceflight could be taken as a compliment measure for the State to implement its authorization obligation as to its national space activities. And space visa should be considered a "responsibility tie" between a launching State and a participant, which could bring more legal certainties when defining the fault attribution.

The birth of private spaceflight industry may arrive in the near future. For the assured survival of the industry, it is important for an adequate body of international rules and the due legal certainties to solve liability issues so that there can be sufficient public and investor confidence in the industry. However, this must be balanced with the desire to avoid imposing too heavy a regulatory burden on start-up operators and, further, to give an unneeded incentive for the phenomenon of the flags of convenience to be replicated from maritime law to space law. Only if this balance can be achieved, can the birth and development of a private spaceflight industry be assured [67].

\section{Data Availability}

The experimental data used to support the findings of this study are available from the corresponding author upon request.

\section{Conflicts of Interest}

The authors declare no conflict of interest.

\section{Acknowledgments}

The authors would like to acknowledge the research is funded partially by the China National Social Science Foundation (16BFX187).

\section{References}

[1] See Stephan Hobe, "Legal Aspects of Space Tourism" (20072008) 86 Neb. L. Rev. 439 at 439, citing Stephan Hobe \& Jurgen Cloppenburg, "Towards a New aerospace Convention? Selected Legal Issues of 'Space Tourism' " Proceedings of the Forty-Seventh Colloquium on the Law of Outer Space (2004), 377; see also Freeland, "Fly me to the Moon", at 98; Charity Trelease Ryabinkin, 'Let there be flight: it's time to reform the regulation of commercial space travel' (2004) 69 Journal of Air Law and Commerce 101, 103; Peter van Fenema, Suborbital Flights and ICAO, 30 AIR \& SPACE LAw 396, 405 (2005). at 402; Brannen, supra note 11 at 642.

[2] Stephan Hobe \& Juirgen Cloppenburg, Towards a New Aerospace Convention? Selected Legal Issues of" Space Tourism, "PROCEEDINGS OF THE FORTY-SEVENTH COILOQUIUM ON THE LAW OF OUTER SPACE, 377, 377 (2004).

[3] This double criterion is formulated to exclude scenarios where governments or intergovernmental organizations pay for the flight of a particular human and undertake the actual flight operations, in which case the flight is legally speaking still comprehensively 'public' in nature. Flights such as carried out by private operators on behalf of NASA however are still included by virtue of criterion (b), whereas flights such as those of Mr. Dennis Tito to the ISS remain included by virtue of criterion (a). See for further analysis Frans G. von der Dunk, Legal Aspects of Private Manned Spaceflight, in HANDBOOK OF SPACE LAW 266-67 (ed. Frans G. von der Dunk 2015); cf. E. Walter, The Privatisation and Commercialisation of Outer Space, in OUTER SPACE IN SOCIETY, POLITICS AND LAW 496-500 (eds. C. Brünner \& A. Soucek 2011); M. Gerhard, Article VI in COLOGNE COMMENTARY ON SPACE LAW, VOL. I 110-4 (eds. S. Hobe, B. Schmidt-Tedd \& K.U. Schrogl 2009); and P. Atrey, Space Tourism - Future Industry, in in CURRENT DEVELOPMENTS IN AIR AND SPACE LAW 417-29 (eds. R. Singh, S.D. Rao \& S. Kaul 2012).

[4] Passing the Buck to Rogers: International Liability Issues in Private Spaceflight, see StevenFreeland, The Impact of Space Tourism on the InternationalLaw of Outer Space, PROCEEDINGS OF THE FORTY-EIGHTH COLLOQUIUM ON THE LAW OF OUTER SPACE 178, at 179.

[5] P. van Fenema, "Suborbital Flights and ICAO," 30 Air \& Space $L A w$, vol. 396, p. 405, 2005.

[6] For a full discussion on this subject cf. Commentary, Article I.. 
[7] See Ryabinkin, Charity Trelease Ryabinkin, Let there be flight: it's time to reform the regulation of commercial space travel, 69 J. AIR L. \& COM. 101, 119 (2004) (highlighting the importance of liability insurance to the commercial launch industry., at 119-20 (describing the challenges to the reusable launch vehicle (RLV) industry posed by the existing regulatory regime, including the current liability and indemnification provisions). Rebekah Davis Reed, Ad Astra Per Aspera: Shaping a Liability Regime for the Future of Space Tourism, 46 Hous. L. Rev. 585, 614 (2009), at 588.

[8] S. Hobe, "Legal Aspects of Space Tourism," 86 Neb. L. Rev., vol. 439 , p. 458,2007 , at 448 .

[9] See Stephan Hobe, Legal Aspects of Space Tourism, 86 Neb. L. Rev. (2007), at 451-454; Stephan Hobe, The legal regime for private space tourism activities-an overview, University of Cologne, Institute of Air and Space Law, Albertus-MagnusPlatz, Cologne, Germany. (2010), at 1595; Dunk, F.G. von der, "Effective exercise of 'In-space Jurisdiction': the US approach and the problems it is facing", Journal of space law: a journal devoted to the legal problems arising out of man's activities in outer space, 40 (2015-2016), No. 1-2, at147-155; Albert, C., "Liability in International Law and the Ramifications on Commercial Space Launches and Space Tourism", Loyola of Los Angeles international and comparative law review, (2014), No. 2, at 233-243; Juan Davalos, International Standards in Regulating Space Travel: Clarifying Ambiguities in the Commercial Era of Outer Space, Emory Int'l L. Rev. (2016), at598-610; Benjamyn Ian Scott, International Suborbital Passenger Transportation: An Analysis of the Current Legal Situation of Transit and Traffic Rights and Its Appropriate Regulation, 14 Issues Aviation L. \& Pol'y (2015), at277-300; Reaven, E., "The United States Commercial Space Launch Competitiveness Act: The Creation of Private Space Property Rights and the Omission of the Right to Freedom from Harmful Interference", Washington University law review, 94 (2016), No. 1, at 233-260.

[10] See Extension of Space Launch Indemnification:Hearing Before the Subcomm. on Space \& Aeronauticsof the H. Comm. on Science, 106th Cong. 1-2 (1999) (statement of Rep. Dana Rohrabacher, Chairman, H. Subcomm. on Space \& Aeronautics) (reviewing the strength of the U.S. commercial space launch industry); ASSOC. ADM'R FOR COMMERCIAL SPACE TRANSP., U.S. DEPT. OF TRANSP., LIABILITY RISK-SHARING REGIME FOR U.S. COMMERCIAL SPACE TRANSPORTATION: STUDY AND ANALYSIS 3 (2002) [hereinafter LIABILITY RISK-SHARING REGIME], available at http://www.faa.gov/about/office-org/ headquartersoffices/ast/media/FAALiabilityRiskSharing4-02 .pdf (reviewing public comments on the existing liability regime and industry views in an effort to improve the U.S. launch industry); Ryabinkin, supra note 4, at 136 ("[I]f tourism is to become a vital part of the commercial space equation, limits on liability for the owners and operators of space facilities and vehicles will be a necessity." (quoting Patrick Collins, The Regulatory Reform Agenda for the Era of Passenger Space Transportation (Univ. of Tokyo, Research Ctr. for Advanced Sci., Paper No. 96-f-13, 1996), available at http'/http://www .spacefuture.com/archivel the-regulatoryre form.agenda for the-era of-passenger.space.transportation.shtml)).

[11] See Frans G. von der Dunk, Passing the Buck to Rogers: International Liability Issues in Private Spaceflight, 86 Neb. L. Rev. (2007), at 410-417; Albert, C., "Liability in International Law and the Ramifications on Commercial Space Launches and
Space Tourism", Loyola of Los Angeles international and comparative law review, (2014), No. 2, at 243-246; Benjamyn Ian Scott, International Suborbital Passenger Transportation: An Analysis of the Current Legal Situation of Transit and Traffic Rights and Its Appropriate Regulation, 14 Issues Aviation L. \& Pol'y (2015), pp. 300-311; Rebekah Davis Reed, Ad Astra Per Aspera: Shaping a Liability Regime for the Future of Space Tourism, 46 Hous. L. Rev. (2009), at 590-592.

[12] Convention on International Liability for Damage Caused by Space Objects, opened for signature Mar. 29, 1972, 24 U.S.T. 2389, 961 U.N.T.S. 187 [hereafter Liability Convention].

[13] S. Hobe, "Legal Aspects of Space Tourism," 86 Neb.L.Rev., vol. 439 , p. 458, 2007, at 450.

[14] Id. At 458.

[15] Id. At 450.

[16] Convention on International Liability for Damage Caused by Space Objects, opened for signature Mar. 29, 1972, 24 U.S.T. 2389, 961 U.N.T.S. 187 [hereafter Liability Convention].

[17] Id. Art. VIII.

[18] Id. Art. VIII.

[19] L. J. Smith and A. Kerrest, “Article VIII LIAB," in Cologne Commentary on Space Law, Volume II, S. Hobe, B. SchmidtTedd, and K.-U. Schrogl, Eds., Heymanns, Cologne, 2013, at 156.

[20] Art. VIII, LC.

[21] Id. Art. II.

[22] Id. Art. III.

[23] Convention on International Liability for Damage Caused by Space Objects, opened for signature Mar. 29, 1972, 24 U.S.T. 2389, 961 U.N.T.S. 187 [hereafter Liability Convention]. Para.2, Art.VIII.

[24] L. J. Smith and A. Kerrest, "Article VIII LIAB," in Cologne Commentary on Space Law, Volume II, S. Hobe, B. SchmidtTedd, and K.-U. Schrogl, Eds., Heymanns, Cologne, 2013, at 157.

[25] B. Cheng, Studies in International Space Law, Oxford University Press Inc., New York, NY, USA, 1997, at 73.

[26] I. Brownlie, Principles of Public International Law, Oxford University Press, Oxford, 7th edition, 2008, at 477.: with reference to the Nottebohm Case, (Liechtenstein v. Guatemala) (Second Phase Judgement) [1995] ICJ Rep. 4.

[27] Art. VIII, LC.

[28] I. Brownlie, Principles of Public International Law, Oxford University Press, Oxford, 7th edition, 2008, at 477.: with reference to the Nottebohm Case, (Liechtenstein v. Guatemala) (Second Phase Judgement) [1995] ICJ Rep. 4.

[29] Treaty on Principles Governing the Activities of States in the Exploration and Use of Outer Space, including the Moon and Other Celestial Bodies London/Moscow/Wash- ington, opened for signature Jan. 27, 1967, 18 U.S.T. 2410, 610 U.N.T.S. 205 [hereafter Outer Space Treaty].

[30] Ibid..

[31] P. J. Blount, "Jurisdiction in Outer Space: Challenges of Private Individuals in Space," 33 J. Space L., vol. 299, p. 340, 2007, at 333-339.

[32] Id. Art. II.

[33] L. J. Smith and A. Kerrest, “Article II LIAB," in Cologne Commentary on Space Law, Volume II, S. Hobe, B. Schmidt-Tedd, and K.-U. Schrogl, Eds., Heymanns, Cologne, 2013, at 116.

[34] Id. At 118. 
[35] Art. 31, 1967 Vienna Convention on the Law of Treaties.

[36] See G. Schwarzenberger, 1 International Law (1957), at 590.

[37] L. J. Smith and A. Kerrest, "Article II LIAB," in Cologne Commentary on Space Law, Volume II, S. Hobe, B. Schmidt-Tedd, and S. Kai-Uwe, Eds., Heymanns, Cologne, 2013, at 106.

[38] Id. at 132.

[39] S. Hobe, "Legal Aspects of Space Tourism," 86 Neb.L.Rev., vol. 439, p. 458, 2007, at 450 .

[40] Convention on International Liability for Damage Caused by Space Objects, opened for signature Mar. 29, 1972, 24 U.S.T. 2389, 961 U.N.T.S. 187 [hereafter Liability Convention].

[41] Id. Art. XXIII.

[42] https://www.virgingalactic.com/human-spaceflight/ourvehicles/, 2018.1.5.

[43] S. Hobe, "Legal Aspects of Space Tourism," 86 Neb.L.Rev., vol. 439, p. 458, 2007, at 448-449.

[44] Convention on International Liability for Damage Caused by Space Objects, opened for signature Mar. 29, 1972, 24 U.S.T. 2389, 961 U.N.T.S. 187 [hereafter Liability Convention].

[45] L. J. Smith and A. Kerrest, “Article II LIAB," in Cologne Commentary on Space Law, Volume II, S. Hobe, B. Schmidt-Tedd, and K.-U. Schrogl, Eds., Heymanns, Cologne, 2013, at 132.

[46] Ibid. At 126.

[47] Convention on International Liability for Damage Caused by Space Objects, opened for signature Mar. 29, 1972, 24 U.S.T. 2389, 961 U.N.T.S. 187 [hereafter Liability Convention].

[48] Ibid..

[49] S. Hobe, "Legal Aspects of Space Tourism," 86 Neb.L.Rev., vol. 439, p. 458, 2007, at 455.

[50] Black's Law Dictionary, 8th edition, , 2004at 2490.

[51] B. Cheng, Studies in International Space Law, Oxford University Press Inc., New York, NY, USA, 1997, at 231.

[52] See USSR, A/AC.105/C.2/SR.66(25.7.1866), P.11: 'the text... covered both the object launched into space and its crew, whether the latter was inside or outside the object'.

[53] The terms personnel and crew seem to have been treated as synonyms.

[54] B. Cheng, Studies in International Space Law, Oxford University Press Inc., New York, NY, USA, 1997, at 232.

[55] See Id. At 634.

[56] Treaty on Principles Governing the Activities of States in the Exploration and Use of Outer Space, including the Moon and Other Celestial Bodies London/Moscow/Wash- ington, opened for signature Jan. 27, 1967, 18 U.S.T. 2410, 610 U.N.T.S. 205 [hereafter Outer Space Treaty].

[57] See Article VI and Article II , in: Hobe, Stephan/SchmidtTedd, Bernhard/Schrogl, Kai-Uwe(eds.), Cologne Commentary on Space Law, Volume I, Heymanns, Cologne 2009.

[58] M. Gerhard, "Article VI," in Cologne Commentary on Space Law, Volume I, S. Hobe, B. Schmidt-Tedd, and K.-U. Schrogl, Eds., Heymanns, Cologne, 2009, at 110.

[59] See Xinhua Dictionary, 1999, at 786.

[60] Treaty on Principles Governing the Activities of States in the Exploration and Use of Outer Space, including the Moon and Other Celestial Bodies London/Moscow/Wash- ington, opened for signature Jan. 27, 1967, 18 U.S.T. 2410, 610 U.N.T.S. 205 [hereafter Outer Space Treaty].

[61] M. Gerhard, "Article VI," in Cologne Commentary on Space Law, Volume I, S. Hobe, B. Schmidt-Tedd, and K.-U. Schrogl, Eds., Heymanns, Cologne, 2009, at 117.
[62] Convention on International Liability for Damage Caused by Space Objects, opened for signature Mar. 29, 1972, 24 U.S.T. 2389, 961 U.N.T.S. 187 [hereafter Liability Convention].

[63] M. Gerhard, "Article VI," in Cologne Commentary on Space Law, Volume I, S. Hobe, B. Schmidt-Tedd, and K.-U. Schrogl, Eds., Heymanns, Cologne, 2009, at 249.

[64] P. J. Blount, "Jurisdiction in Outer Space: Challenges of Private Individuals in Space," 33 J. Space L, vol. 299, p. 340, 2007, at 334.

[65] Id.

[66] S. Hobe, G. M. Goh, and J. Neumann, "Space Tourism Activities-Emerging Challenges to Air and Space Law?," $33 \mathrm{~J}$. SPACE. L., vol. 373, 2007.

[67] R. J. Lee and S. L. Steele, "Modes for Codifying International Rules for Jurisdiction, Liability, Safety and Accident Investigation for Commercial Passenger Spaceflight," 83 Nordic J. Int'l $L$, vol. 251, p. 292, 2014, at 292. 